\title{
Financial Ratio Analysis of Pine Sap Commodity: Case Study on Community Forest Area in Indonesia
}

\author{
Andi Mawaddah Zakiyah ${ }^{1}$, Makkarennu ${ }^{1 *}$, Ridwan ${ }^{1}$ \\ ${ }^{\#}$ Faculty of Forestry, Universitas Hasanuddin, Jl. Perintis Kemerdekaan Km. 10 Tamalanrea, Makassar, South \\ Sulawesi, Indonesia
}

\begin{abstract}
:
Community Forest is a scheme that aims to empower local communities and provide access to manage protected or production forest areas. The pine sap commodity is one of the sources of livelihood for the community by utilizing existing access. Financial ratio analysis is very important to determine the value added of marketing margins and profit margins from the pine sap commodities that have been turned into a product. Respondents were selected based on people who worked as pine sap collectors, from farmers to the pine sap processing industry who bought and processed the pine sap products. The results showed that the pine sap processed by the pine sap processing industry was in the form of gondorukem and turpentine which were then marketed to international markets, namely India, Vietnam, and China with different financial ratios for each business actor.
\end{abstract}

Keywords - Community forestry, pine sap, financial ratio, marketing margin, profit margin.

\section{INTRODUCTION}

Climate change is marked by changes in the world climate patterns, resulting in erratic weather phenomena and greatly affecting human life and natural systems throughout the world [1] [2]. Human activities in the last few years have caused damage to forest areas leading to an increase in carbon emissions by almost $20 \%$ [3]. The benefits of the forest itself are divided into two, namely tangible benefits which is the form of tangible materials and intangible benefits which cannot be assessed or touched by the market system [4]. Non-timber forest products (NTFPs) are forest resources that have advantages and contribute to community welfare through increased income [5]. NTFPs are all goods or materials taken from the forest other than wood used for household needs or marketed [6].

Pinus merkusii is the only pine species that spreads naturally in the southern equator with an height range between 30-1800 meters above sea level but is threatened with extinction because its habitat is starting to be damaged and overexploited for its timber and sap [7]. Pine sap is one of the NTFPs managed by the community around the forest area. Pine sap is one of the NTFPs with commercial value and potential to be developed at this time [8]. Pine sap as a NTFP commodity is crucial in the forestry sector and provides benefits in the industrial sector. In addition, NTFPs can maintain forest sustainability because the harvesting process can be carried out sustainably without damaging the forest [9].

Currently, the marketing flow of pine sap reaches the local market, the national market, and even the international market. One of the regencies in Indonesia that has launched the Community Forest social forestry program is Soppeng Regency with the main use being aimed at empowering local communities. The goal is that protected forest areas and production forests that have not been encumbered with management rights or utilization permits become a source of livelihood for the local community, permits are granted to local community groups [10] in which there is use of NTFPs in the form of pine sap. One of them is managed by the Cempalagie Forest Farmers Group (FFG). 
DOI: $\underline{10.51386 / 25815946 / i j s m s-v 4 i 5 p 124}$

Volume: 4 Issue: 5

September to October 2021

https://www.ijsmsjournal.org

The change of raw material for pine sap into a product goes through several stages. Analysis of financial ratios in the form of marketing margins and profit margins of the pine sap needs to be done to find out the which business actors get the biggest profits and added value to find out how much material for the services provided. That way, it can provide an overview of the advantages and improvements as well as significant developments for the pine sap processing industry. In addition, it provides quite complete information for actors as well as investors and workers. This background indicates the need for this research.

\section{LITERATURE REVIEW}

\section{A. Community Forest}

Community Forest $(\mathrm{CF})$ is one of the Social Forestry schemes where the management of the work area applies an agroforestry system [11]. This activity is carried out through providing legal access to local communities, including through the CF program on state forest land and explaining that the purpose of the $\mathrm{CF}$ program is to improve community welfare through optimal, fair, and sustainable use of forest resources while maintaining the preservation of forest functions.

Through CF development, communities who live in and around forests are treated and recognized as an inseparable part of an ecosystem that influences and depends on each other [12]. CF is expected to be able to improve the welfare of local communities through optimal, fair, and sustainable use of forest resources while maintaining the preservation of forest functions and the environment [13].

The issuance of a Community Forest Utilization Business Permit gives rights to communities or groups to utilize forest areas in the form of timber and non-timber forest products [14]. Its activities include breeding, planting, maintaining, harvesting, processing, and marketing based on the principles of forest, social, and environmental sustainability, or in the form of utilization (ecotourism services, biodiversity services, carbon sequestration/storage services).

\section{B. Pine Sap}

Pine sap production is affected by internal and external factors. The internal factors come from the nature of the tree and the external factors come from the environment [15]. The increase in pine sap productivity occurs as the diameter of the tree itself increases [16]. The results of research conducted by Sukarno, et al (2012) showed that the production of pine sap among age classes showed significant differences. The production of latex in the III age class (36.5 g / 2 holes / 1 day) increased in the IV age class (62.9 g / 2 holes / 1 day) and decreased in the $\mathrm{V}$ age class $(24.61 \mathrm{~g} / 2$ holes / 1 day). The production of latex at the VI age class (38.3 g / 2 holes / 1 day) is almost the same as the III age class. In normal tree growth, tapping the sap for the first time (open tapping) can be done at the III age class (11-15 years old) [17].

Pine sap is a kind of oleoresin which is a complex mixture of resin and turpentine in the form of a thick and sticky, clear or opaque liquid. The sap or resin is formed as a result of secondary metabolic processes in the tree. The sap serves to protect growing cells and stimulate growth activity for mechanical wound closure in the event of pest and disease attacks. Pine sap is obtained when pine tree trunks are injured (tapped). The principle of secretion of sap from the wound is that the ducts on all sides are surrounded by parenchyma tissue and there is an osmotic balance between the ducts and the parenchyma cells. If a cut is made on the pine trunk, the sap channel will open which causes the wall pressure to open, so that the sap comes out [15].

The production of pine sap starts from the wounding of the bark of the pine tree. There are two forms of lymphatic channels, namely normal and traumatic channels. Traumatic pine sap duct-forming associated with injuries or traumatic events to trees. Injury to pine wood causes the release of pine sap through the wound and may be followed by the formation of new cells that produce pine sap around the wound [18]. The tapping systems or techniques that are often used to harvest pine sap include [15]:

1. Scraping System

This technique is done by scraping the bark first, then the wood is cut as deep as $1-2 \mathrm{~cm}$, while the width is $10 \mathrm{~cm}$. The wound in this way forms an inverted $U$ with about $15-20 \mathrm{~cm}$ from the ground.

2. Corporal System 
DOI: $\underline{10.51386 / 25815946 / \mathrm{ijsms}-\mathrm{v} 4 \mathrm{i} 5 \mathrm{p} 124}$

Volume: 4 Issue: 5

September to October 2021

https://www.ijsmsjournal.org

This technique is almost the same as the scraping technique, but the V-shaped can also be modified into a double $\mathrm{V}$ or a series towards the top (rill) which is shaped like a fish fin, wound with a width of $15 \mathrm{~cm}$, a depth of $1 \mathrm{~cm}$.

3. Drill System

This technique uses an electric drill equipped with a jenset. The tapping wound is made from the base of the stem towards the top, the tapping wound is in the form of a hole with a diameter of $2.2 \mathrm{~cm}$ with a depth of $4-8 \mathrm{~cm}$.

\section{Financial Ratios (Marketing Margin and Profit Margin)}

Marketing margin is the difference between the price paid by consumers and the price received by farmers or is the cost of marketing services needed as a result of demand and marketing services [19]. The greater the price difference between the trading system institutions involved, especially between the prices that occur at the retail level and the prices received by farmers, the greater the margin of the trade system for the commodity concerned. Another opinion was expressed by Desiana, et al (2017) that marketing margin is the difference between the price received by producers and the price paid by consumers and is expressed in units of rupiah per kilogram (IDR/kg). The marketing margin is basically the sum of the marketing costs and profits of the institutions that provide services in the marketing process. In essence, the marketing margin is the difference between the price at the farm level as a producer and the price at the consumer level [20].

The value of the marketing margin can be determined by calculating the costs incurred and the profits of the marketing institutions that take part in the marketing process [21]. The larger the marketing margin, the lower the price received by producers, while the higher the price received by consumers [22]. Marketing margin is determined by the amount of marketing costs involved in marketing activities in order to determine the marketing efficiency of a product from the producer level to the consumer level [23]. The marketing margin in this research is calculated as the difference between the selling price of pine sap at the farmer level and the selling price of pine sap at the intermediary level. The value of the marketing margin for each marketing actor will be tested using a cost margin analysis tool, namely by calculating the amount of marketing margin, costs, and marketing profits obtained by farmers.

\section{III.RESEARCH METHODOLOGY}

\section{A. Research Method}

This research uses qualitative and quantitative methods with a descriptive approach. Qualitative methods can be interpreted as research that produces descriptive data in the form of speech, writing, and behavior from the people observed [26] which will be obtained through interviews and field observations. The quantitative method can be interpreted as research that produces data in the form of numbers that can be calculated which will be obtained through the calculation of marketing margins and profit margins of the pine sap value chain. Research through this descriptive approach is a form of research aimed at describing existing phenomena in the form of forms, activities, characteristics, changes, and relationship [27].

\section{B. Study Site and Participants}

This research was located in Ara Hamlet, Pesse Village, Donri-Donri District, Soppeng Regency, Indonesia. Part of this research were 30 members of Cempalagie FFG (Forest Farmers Group), Soppeng Regency, and the head of the farmer group is the collector trader. A search for the pine sap processing industry players will also be carried out which is determined intentionally (purposive sampling) with the criteria that the respondent is a buyer of pine sap from Soppeng Regency which in this case is PT Istana Palapa Kertas (ISPAK) Jakarta.

\section{Instruments}

\section{1) Observation}

The direct observation technique is carried out by collecting data through observing and recording the symptoms that appear on the object of research whose implementation is directly in the place and situation carried out by the researcher, namely by direct observation to the pine sap tapping land and observing and identifying the activities carried out. 


\section{DOI: $\underline{10.51386 / 25815946 / \mathrm{ijsms}-\mathrm{v} 4 \mathrm{i} 5 \mathrm{p} 124}$}

Volume: 4 Issue: 5

September to October 2021

https://www.ijsmsjournal.org

\section{2) Interviews}

Direct communication techniques (interviews) are carried out by collecting data through direct verbal or face-toface contact with respondents, namely members of pine sap tapping farmer groups and pine sap commodity business actors through questions and answers with the help of interview guides.

\section{3) Literature Study}

Literature study is carried out through the collection of secondary data that supports research through quoting and recording data from village, sub-district, and agencies related to research.

\section{4) Documentation}

Documentation is done by taking pictures on various objects to provide a clearer and more detailed picture of the topic or object being discussed.

\section{Data Analysis}

The instruments used in pine sap marketing are marketing margin and profit margin. The profit margin is the accumulated profit received from the difference between the purchase price and the selling price of each pine sap marketer calculated in IDR/kg/day [24] (1\$ = IDR 14.149,05). The calculation of the margin of each marketing agency uses the following formula [25]:

$$
M p=P r-P f \text { atau } M p=B p+K p
$$

Information:

$$
\begin{aligned}
M p & =\text { Marketing margin }(I D R / \mathrm{kg}) \\
P r & =\text { Price at the consumer level }(I D R / \mathrm{kg}) \\
P f & =\text { Price at the producer level }(I D R / \mathrm{kg}) \\
B p & =\text { Marketing costs }(I D R / \mathrm{kg}) \\
K p & =\text { Profit }(I D R / \mathrm{kg})
\end{aligned}
$$

In addition, to calculating the marketing margin of each actor, it is also necessary to know the distribution of added value received by each actor. It aims to find out which business actors get the most profit. The profit margin formula used is as follows:

$$
\boldsymbol{\pi}=\boldsymbol{P a}-\boldsymbol{P b}-\boldsymbol{C}
$$

Information:

$\pi \quad=$ Profits received by each actor

$\mathrm{Pa}=$ Selling price for each actor $(I D R)$

$\mathrm{Pb}=$ Purchase price of the product for each actor (IDR)

$C \quad=$ Marketing costs per actor (IDR)

\section{IV.FINDING AND DISCUSSION}

The marketing of pine sap from the Cempalagie community forest has reached the international market through several actors, namely from pine sap tapping farmers, to collectors, then to the pine sap processing industry, namely PT ISPAK which is located in Jakarta and has marketed pine sap and latex products in the form of gondorukem and turpentine to India, Vietnam, and China. 
DOI: $\underline{10.51386 / 25815946 / \mathrm{ijsms}-\mathrm{v} 4 \mathrm{i} 5 \mathrm{p} 124}$

Volume: 4 Issue: 5

September to October 2021

https://www.ijsmsjournal.org

\section{A. Financial Ratio}

The series of activities that occur in a chain are carried out separately but are highly dependent on each other, starting from raw materials to becoming a product and after-sales handling. Market chain actors for pine sap commodities in Cempalagie FFG consist of pine sap tapping farmers, collector traders, wholesalers, namely the pine sap processing industry (PT ISPAK), and consumer countries, namely India, Vietnam, and China. The pine sap market chain in Cempalagie FFG is presented in Figure 1.

Figure 1 Pine Sap Market Chain
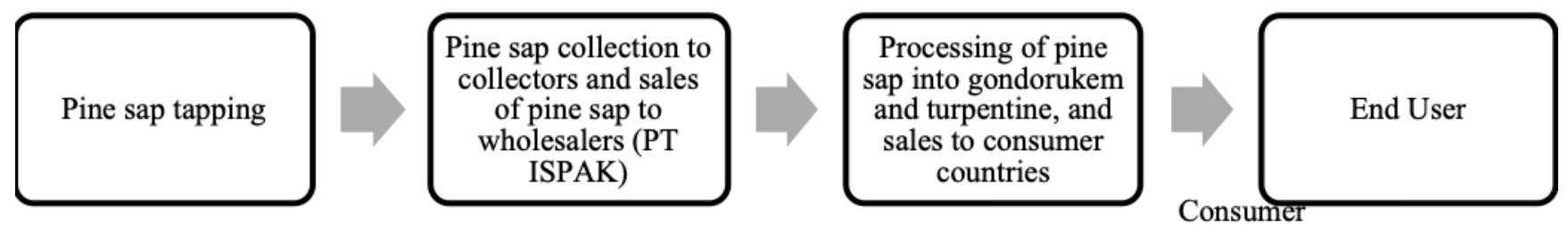

Consumer

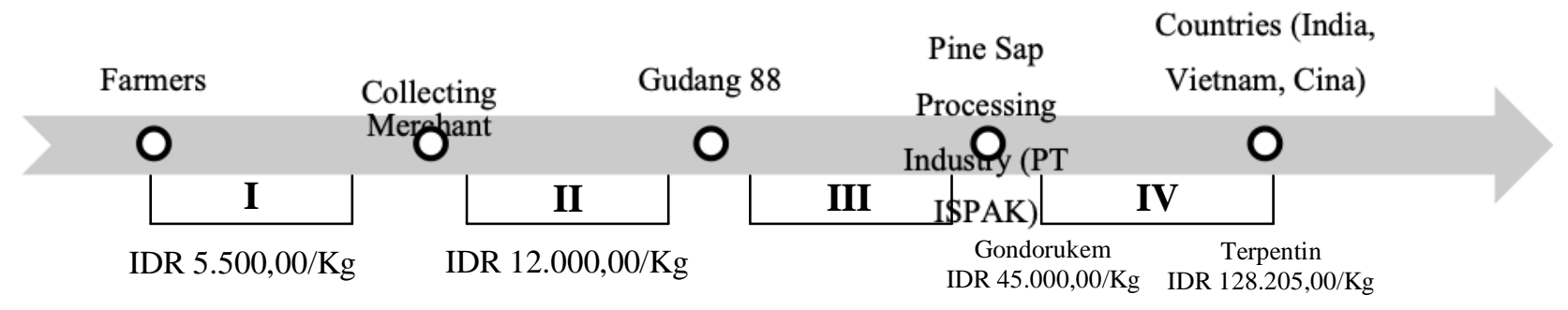

\section{1) The Marketing Margin}

The marketing aspect is essential in marketing agricultural products. If the marketing mechanism is good, then all parties involved will benefit so that the marketing channel has a very important role [28]. Marketing is a social process, both individuals and groups involved in the process, in obtaining what is needed and wanted by creating, offering, and exchanging products or services of value with other parties [29]. The marketing margin shows the difference between the selling price and the purchase price for each business actor. This value will be reduced by the acquisition cost in the IV marketing channel because there has been a raw material processing process by multiplying the product price by the contribution of other inputs and then adding the price of additional materials, then the product price is reduced by the calculation results. The results show that the largest margin is at the level of the fourth marketing channel, namely wholesalers (pine sap processing industry) because they have processed pine sap into the final product.

The marketing margin for the final product of pine sap is in the form of gondorukem which is shown in table 1 , in the I marketing channel, the selling price at the farmer level is very low at IDR 5,500.00/kg and does not carry out marketing activities because the pine sap is sold directly to the collectors. The II marketing channel shows that the selling price to the collector traders has more than doubled, which is IDR $12,000.00 / \mathrm{kg}$ so that the marketing margin of the collector traders is IDR $6,500.00 / \mathrm{kg}$. In the III marketing channel, there is no buying and selling process because it is only in the form of sending pine sap to the processing industry, namely PT ISPAK so that no marketing margin is formed. The IV marketing channel shows a change in the shape of the product so that an acquisition cost of IDR $21,983.00 / \mathrm{kg}$ with the price of gondorukem sold to consumer countries increases more than double the purchase price, which is IDR 45,000.00/kg. Therefore. the marketing margin is IDR $11,017.00 / \mathrm{kg}$. 
DOI: $\underline{10.51386 / 25815946 / \mathrm{ijsms}-\mathrm{v} 4 \mathrm{i} 5 \mathrm{p} 124}$

Volume: 4 Issue: 5

September to October 2021

https://www.ijsmsjournal.org

Table 1 The Marketing Margin of Gondorukem Product

\begin{tabular}{|c|c|c|c|c|c|}
\hline $\begin{array}{c}\text { Marketing } \\
\text { Channel }\end{array}$ & Marketing Agency & $\begin{array}{c}\text { Purchase Price } \\
\text { (IDR/kg) }\end{array}$ & $\begin{array}{c}\text { Selling Price } \\
\text { (IDR/kg) }\end{array}$ & $\begin{array}{c}\text { Cost of } \\
\text { Acquisition } \\
\text { (IDR/kg) }\end{array}$ & $\begin{array}{c}\text { Marketing } \\
\text { Margin } \\
\text { (IDR/kg) }\end{array}$ \\
\hline I & $\begin{array}{c}\text { Farmers to collector } \\
\text { traders }\end{array}$ & - & 5,500 & - \\
\hline II & $\begin{array}{c}\text { Collectors to the } \\
\text { wholesaler, Gudang } 88\end{array}$ & 5,500 & 12,000 & - \\
\hline III & $\begin{array}{c}\text { Gudang 88 to PT } \\
\text { ISPAK }\end{array}$ & - & - & 6,500 \\
\hline IV & $\begin{array}{c}\text { PT ISPAK to } \\
\text { Consumer Countries }\end{array}$ & 12,000 & 45,000 & 21,983 & - \\
\hline
\end{tabular}

The marketing margin for the final product of pine sap is in the form of turpentine which is shown in table 2. In the I marketing channel, the selling price at the farmer level is still IDR 5,500.00/kg and does not carry out marketing activities because the pine sap is sold directly to the collectors. The II marketing channel shows that the selling price to collectors has more than doubled by IDR $12,000.00 / \mathrm{kg}$, so that the marketing margin of collectors is IDR $6,500.00 / \mathrm{kg}$. There is no buying and selling process in the III marketing channel because it is only in the form of sending pine sap to the processing industry, namely PT ISPAK, so there is no marketing margin formed. The IV marketing channel shows a change in the shape of the product so that an acquisition cost of IDR $72,751.00 / \mathrm{kg}$ with the price of turpentine sold to consumer countries increases more than ten times from the purchase price, which is IDR $128,205.00 / \mathrm{kg}$ so that the marketing margin is IDR $43,454.00 / \mathrm{kg}$.

Table 2 The Marketing Margin of Turpentine Product

\begin{tabular}{|c|c|c|c|c|c|}
\hline $\begin{array}{l}\text { Marketing } \\
\text { Channel }\end{array}$ & Marketing Agency & $\begin{array}{c}\text { Purchase } \\
\text { Price (IDR/kg) }\end{array}$ & $\begin{array}{l}\text { Selling Price } \\
\text { (IDR/kg) }\end{array}$ & $\begin{array}{c}\text { Cost of } \\
\text { Acquisition } \\
\text { (IDR/kg) }\end{array}$ & $\begin{array}{c}\text { Marketing } \\
\text { Margin } \\
\text { (IDR/kg) } \\
\end{array}$ \\
\hline I & $\begin{array}{c}\text { Farmers to collector } \\
\text { traders }\end{array}$ & - & 5,500 & - & - \\
\hline II & $\begin{array}{c}\text { Collectors to the } \\
\text { wholesaler, Gudang } 88\end{array}$ & 5,500 & 12,000 & - & 6,500 \\
\hline III & $\begin{array}{l}\text { Gudang } 88 \text { to PT } \\
\text { ISPAK }\end{array}$ & - & - & - & - \\
\hline IV & $\begin{array}{c}\text { PT ISPAK to } \\
\text { Consumer Countries }\end{array}$ & 12,000 & 128,205 & 72,751 & 43,454 \\
\hline
\end{tabular}

\section{2) The Profit Margin}

Profit margin shows the difference between the selling price and the purchase price which is then reduced by marketing costs for each product sale. Not only calculating the marketing margin of each actor, but also calculating the profit margin to find out the distribution of added value received by each actor along the pine sap marketing chain in Cempalagie CF which aims to find out which actor gets the most profit [30]. The results show that the largest profit margin is at the fourth marketing channel, namely wholesalers (pine sap processing industry) because they have processed pine sap into final products and exported to consumer countries, namely India, Vietnam, and China. The profit margin of the final product of pine sap in the form of gondorukem shows that in the I marketing channel, the selling price at the farmer level is very low, which is IDR 5,500.00/kg, and there is no purchase or marketing activity because the pine sap is sold directly to collectors so that it has fixed profit margin of IDR $5,500 / \mathrm{kg}$. The III marketing channel shows the selling price to collectors is IDR $12,000.00 / \mathrm{kg}$ and marketing costs are obtained from local taxes and expedition costs with a total marketing cost 
DOI: $\underline{10.51386 / 25815946 / \mathrm{ijsms}-\mathrm{v} 4 \mathrm{i} 5 \mathrm{p} 124}$

Volume: 4 Issue: 5

September to October 2021

https://www.ijsmsjournal.org

of IDR $668.00 / \mathrm{kg}$, so that the profit margin of collectors is IDR 5,832.00/ $\mathrm{kg}$. There is no buying and selling process in marketing channel III because it is only in the form of shipping pine sap to the processing industry, namely PT ISPAK, so that no profit margin is formed. The IV marketing channel shows that the selling price of gondorukem is IDR $45,000.00 / \mathrm{kg}$ and marketing costs are obtained from ship service fees, transportation fees, export card fees, and bank payments with a total of IDR $447.00 / \mathrm{kg}$ so that the profit margin is IDR $32,553,00 / \mathrm{kg}$.

Table 3 The Profit Margin for Gondorukem Products

\begin{tabular}{|c|c|c|c|c|c|}
\hline $\begin{array}{l}\text { Marketing } \\
\text { Channel }\end{array}$ & Marketing Agency & $\begin{array}{c}\text { Purchase } \\
\text { Price } \\
\text { (IDR/kg) } \\
\end{array}$ & $\begin{array}{l}\text { Selling Price } \\
\text { (IDR/kg) }\end{array}$ & $\begin{array}{c}\text { Cost of } \\
\text { Acquisition } \\
\text { (IDR/kg) }\end{array}$ & $\begin{array}{c}\text { Marketing } \\
\text { Margin } \\
\text { (IDR/kg) } \\
\end{array}$ \\
\hline I & $\begin{array}{l}\text { Farmers to collector } \\
\text { traders }\end{array}$ & 5,500 & - & - & 5,500 \\
\hline II & $\begin{array}{c}\text { Collectors to the } \\
\text { wholesaler, Gudang } 88\end{array}$ & 12,000 & 5,500 & 668 & 5,832 \\
\hline III & $\begin{array}{l}\text { Gudang } 88 \text { to PT } \\
\text { ISPAK }\end{array}$ & - & - & - & - \\
\hline IV & $\begin{array}{c}\text { PT ISPAK to } \\
\text { Consumer Countries }\end{array}$ & 45,000 & 12,000 & 447 & 32,553 \\
\hline
\end{tabular}

The profit margin of the final product of pine sap is in the form of turpentine. Table 4 shows that in the I marketing channel, the selling price at the farmer level remains at IDR 5,500.00/ $\mathrm{kg}$ and there are no purchases and marketing activities because the pine sap is sold directly to the collectors so that the profit margin remains at IDR $5,500.00 / \mathrm{kg}$. The II marketing channel shows that the selling price to collectors is IDR $12,000.00 / \mathrm{kg}$ and the marketing costs are obtained from local taxes and expedition costs with a total marketing cost of IDR $668.00 / \mathrm{kg}$ so that the profit margin of collectors is IDR $5,832.00 / \mathrm{kg}$. There is no buying and selling process in the III marketing channel because it is only in the form of shipping pine sap to the processing industry, namely PT ISPAK, so that no profit margin is formed. The IV marketing channel shows that the price of turpentine sold at IDR $128,205.00 / \mathrm{kg}$ and the marketing costs are obtained from ship service fees, transportation costs, export card fees, and bank payments with a total of IDR $447.00 / \mathrm{kg}$ so that the profit margin is IDR $115.758 .00 / \mathrm{kg}$.

Table 4 The Profit Margin for Turpentine Products

\begin{tabular}{|c|c|c|c|c|c|}
\hline $\begin{array}{c}\text { Marketing } \\
\text { Channel }\end{array}$ & Marketing Agency & $\begin{array}{c}\text { Purchase } \\
\text { Price } \\
\text { (IDR/kg) }\end{array}$ & $\begin{array}{c}\text { Selling Price } \\
\text { (IDR/kg) }\end{array}$ & $\begin{array}{c}\text { Cost of } \\
\text { Acquisition } \\
\text { (IDR/kg) }\end{array}$ & $\begin{array}{c}\text { Marketing } \\
\text { Margin } \\
\text { (IDR/kg) }\end{array}$ \\
\hline I & $\begin{array}{c}\text { Farmers to collector } \\
\text { traders }\end{array}$ & 5,500 & - & - & 5,500 \\
\hline II & $\begin{array}{c}\text { Collectors to the } \\
\text { wholesaler, Gudang 88 }\end{array}$ & 12,000 & 5,500 & 668 & 5,832 \\
\hline III & $\begin{array}{c}\text { Gudang 88 to PT } \\
\text { ISPAK }\end{array}$ & - & - & - & - \\
\hline IV & $\begin{array}{c}\text { PT ISPAK to } \\
\text { Consumer Countries }\end{array}$ & 128,205 & 12,000 & 447 & 115,758 \\
\hline
\end{tabular}

The results of the marketing margins and profit margins caclculation show differences in the results obtained in each market chain, starting from farmers, collectors, to wholesalers. The results obtained are different due to the different processes and activities carried out by each market chain actor. It can be seen that the smallest yields were of course obtained by pine sap tapping farmers because they did not do marketing, while the largest results were obtained by wholesalers, namely PT ISPAK, because they had processed raw 


\section{DOI: $10.51386 / 25815946 / \mathrm{ijsms}-\mathrm{v} 4 \mathrm{i} 5 \mathrm{p} 124$}

Volume: 4 Issue: 5

September to October 2021

https://www.ijsmsjournal.org

materials (pine sap) into several products (gondorukem and turpentine) and do marketing to international market. PT ISPAK continues to strive to create the highest quality products and services in Indonesia by standing tall with an excellence reputation and being one of the most trusted companies in Indonesia. PT ISPAK is also the official agent of Perum Perhutani (Indonesian State Forestry Corporation) since 2015 in exporting its products in the form of gondorukem and turpentine.

\section{CONCLUSIONS}

The calculation of financial ratios in the form of marketing margins and profit margins for each final product of pine sap in the form of gondorukem and turpentine shows that in the I marketing channel, namely farmers to collectors, there is no marketing margin formed because farmers do not do marketing, but only direct sales to the collectors and obtain the lowest profit margin which is equivalent to the selling price given to collectors, which is IDR 5,500/kg. Meanwhile, the biggest marketing margin and profit margin are in the IV marketing channel, namely PT ISPAK, to consumer countries because it has processed pine sap raw materials into four products and carried out export activities to consumer countries, namely India, Vietnam, and China.

\section{REFERENCES}

[1] I. N. Hidayati and Suryanto, "Pengaruh Perubahan Iklim Terhadap Produksi," J. Ekon. dan Stud. Pembang., vol. 16, no. April, pp. $42-52,2015$

[2] N. Pumijumnong and K. Palakit, "Effects of climate variability on the annual and intra-annual ring formation of Pinus merkusii growing in central Thailand," Environ. Nat. Resour. J., vol. 18, no. 3, pp. 234-248, 2020.

[3] F. Rasyid, "Permasalahan dan Dampak Kebakaran Hutan," no. 4, pp. 47-59, 2014

[4] Tang, M., Adam, M., dan Abdul, H. "Pemanfaatan Hasil Hutan Bukan Kayu (HHBK) Bambu oleh Masyarakat Terasing (Suku Lauje) di Desa Anggasan Kecamatan Dondo Kabupaten Tolitoli". Jurnal Warta Rimba. Vol 7 (2) : 19, 2019.

[5] E. Insusanty, A. T. Ratnaningsih, and S. R. Prastyaningsih, "Analisis Finansial Hasil Hutan Bukan Kayu (Hhbk) Karet Dan Durian Di Kabupaten Siak,” Wahana For. J. Kehutan., vol. 12, no. 2, pp. 29-40, 2017.

[6] Makkarennu, Caroline, A., and Syahidah. "Performance Measurement of Palm Sugar Business using the Integration of Supply Chain Operation Reference (SCOR) and Objective Matirx (OMAX)". International Journal of Science and Management Studies. Vol 4 (1) : 75 pp. $75-84,2021$

[7] A. K. Das, L. B. Singha, and M. L. Khan, "Community structure and species diversity of Pinus merkusii Jungh. \& de Vriese forest along an altitudinal gradient in Eastern Himalaya, Arunachal Pradesh, India," Trop. Ecol., vol. 58, no. 2, pp. 397-408, 2017.

[8] M. Lempang, "Studi Penyadapan Getah Pinus Cara Bor Dengan Stimulan H2So4,” J. Penelit. Has. Hutan, vol. 35, no. 3, pp. 221$230,2017$.

[9] Mampi, B., Abdul, H., dan Muthmainnah. "Produksi Getah Pinus (Pinus Merkusii Jung et de Vriese) pada Berbagai Diameter Batang Menggunakan Sistem Koakan di Desa Namo Kecamatan Kulawi Kabupaten Sigi. Jurnal Warta Rimba". Vol 6 (3) :42. 2018.

[10] A. M. Rahmina, Yanti Sofia, Edy Marbyanto, "Tata Cara dan Prosedur Pengembangan Program Pengelolaan Hutan Berbasis Masyarakat," no. 41, pp. 1-61, 2012.

[11] E. Puspasari, C. Wulandari, A. Darmawan, and I. S. Banuwa, "Aspek Sosial Ekonomi pada Sistem Agroforestri di Areal Kerja Hutan Kemasyarakatan (HKm) Kabupaten Lampung Barat, Provinsi Lampung,” J. Sylva Lestari, vol. 5, no. 3, p. 95 , 2017.

[12] R. M. Mulyadin, Surati, and K. Ariawan, "Kajian Hutan Kemasyarakatan sebagai Sumber Pendapatan: Kasus di Kabupaten Gunungkidul ( Study of Community Forest as Source of Income : A Case in Gunungkidul Regency , Yogyakarta )," Penelit. Sos. dan Ekon. Kehutanan., vol. 13, no. 1, pp. 13-23, 2016.

[13] R. Nandini, "Evaluasi Pengelolaan Hutan Kemasyarakatan (HKm) pada Hutan Produksi dan Hutan Lindung di Pulau Lombok ( Study of Community Forest ( HKm ) Management on Production Forest and Protected Forest in Lombok Island )," J. Penelit. Hutan Tanam., vol. 10, no. 2, pp. 43-55, 2013.

[14] N. E. Patoding, J. M. Matinahoru, and G. Mardiatmoko, "Analisis Strategi Pengembangan Agroforestri Berdasarkan Rancangan Teknis Iuphkm di Dusun Melinani, Desa Manusela, Kabupaten Maluku Tengah,” J. Hutan Pulau-Pulau Kecil, vol. 2, no. 1, pp. 


\section{DOI: $\underline{10.51386 / 25815946 / i j s m s-v 4 i 5 p 124}$}

Volume: 4 Issue: 5

September to October 2021

https://www.ijsmsjournal.org

70-90, 2018.

[15] J. A. Lateka, T. Manurung, and J. D. Prang, “Analisis Faktor - Faktor yang Mempengaruhi Produksi Getah Pinus di Kabupaten Poso," d'CARTESIAN, vol. 8, no. 2, p. 127, 2019.

[16] D. Evayanti, F. T. Wulandari, and D. S. Rini, "Produktivitas Dan Kualitas Getah Pinus Pehutani Kelas Umur Vii Di Kesatuan Pengelolaan Hutan Jember," J. Belantara, vol. 2, no. 2, p. 127, 2019.

[17] A. Sukarno, E. B. Hardiyanto, S. N. Marsoem, and M. Na, "Pengaruh Perbedaan Kelas Umur terhadap Produktivitas Getah Pinus merkusii Jungh et de Vriese Ras Lahan Jawa melalui Penyadapan Getah Metode Bor Effect Of Among Age Class Differences On Oleoresin Production Pinus merkusii Jungh Et De Vriese Java Land Race,” Pal, vol. 3, no. 1, pp. 28-31, 2012.

[18] Pandiangan, A., Benteng H, S., dan Pamona S. "Produktivitas Penyadapan Getah Pinus di Desa Parhottingan Aek Nauli KPH III Kabupaten Simalungun". Jurnal Akar. Vol 8 (1): 2. 2019.

[19] W. Ariaty, A. Rifai, and E. Maharani, “Analisis Marjin Pemasaran Agroindustri Beras Di Kecamatan Bungaraya Kabupaten Siak,” J. Online Mhs. Fak. Pertan. Univ. Riau, vol. 3, no. 1, pp. 1-6, 2016.

[20] S. Khaswarina, Y. Kusumawaty, and E. Eliza, “Analisis Saluran Pemasaran dan Marjin Pemasaran Bahan Olahan Karet Rakyat (Bokar) di Kabupaten Kampar,” Unri Conf. Ser. Agric. Food Secur., vol. 1, pp. 88-97, 2019.

[21] K. Ningsih, “Analisis Saluran dan Marjin Pemasaran Petani Jambu Air Camplong ( syzygium aqueum ) Of Rose Water Camplong Farmer ( syzygium aqueum ),” pp. 35-45, 2011.

[22] I. Pratiwi, S. Setyowati, and M. T. Sundari, “Analisis Marjin Pemasaran Keripik Ketela Ungu di Kecamatan Tawangmangu Kabupaten Karanganyar,” J. Ekon. Pertan. dan Agribisnis, vol. 3, no. 3, pp. 568-577, 2019.

[23] P. S. Agribisnis and F. Pertanian, "Ruslan, Arifin, Azisah: Marjin Pemasaran Udang Di Desa Ampekale Kecamatan Bontoa Kabupaten Maros," J. Agribis, vol. 11, no. 1, pp. 56-71, 2020.

[24] Basri, H. "Analisis Rantai Pemasaran dan Besar Marjin Pemasaran Ikan Asin pada Tiap Pelaku Pemasaran di Desa Padang Rubek Kecamata Kuala Pesisir Kabupaten Nagan Raya". Fakultas Pertanian, Universitas Teuku Umar, Aceh Barat. 2014.

[25] I. D. Su'udi, "Saluran dan Marjin Pemasaran Gabah Studi Kasus Kecamatan Balen Kabupaten Bojonegoro," Oryza, vol. 4, no. 1, pp. 13-20, 2018.

[26] Ismiyanto, "Metodologi Penelitian,” pp. 50-62, 2003.

[27] M. Linarwati, A. Fathoni, and M. M. Minarsih, "Studi Deskriptif Pelatihan Dan Pengembangan Sumberdaya Manusia Serta Penggunaan Metode Behavioral Event Interview Dalam Merekrut Karyawan Baru Di Bank Mega Cabang Kudus,” J. Manage., vol. 2, no. 2, p. 1, 2016

[28] Iqbal M.I, Mohammad A, Sadat., Azisah. "Analisis Saluran dan Margin Pemasaran Umbi Porang (Studi Kasus di Kelurahan Balleangin Kecamatan Balocci Kabupaten Pangkajene dan Kepulauan)," vol. 12, no. 2, pp. 1-12, 2020.

[29] R. Annisa, S. Marzuki, and W. Roessali, “Analisis Pola Saluran Pemasaran Dan Marjin Serta Efisiensi Pemasaran Ayam Broiler Pada Sistem Kemitraan Di Kabupaten Grobogan (Analysis of The Pattern Marketing Channels And Marketing Margins With Efficiency Of Marketing Broiler Chicken Farming In Grobo,” Anim. Agric. J., vol. 4, no. 1, pp. 144-148, 2015.

[30] Pratama, A., G. "Analisis Rantai Nilai (Value Chain Analysis) Komoditi Sutera di Kabupaten Wajo". Fakultas Kehutanan, Universitas Hasanuddin, Makassar. 2018. 